\title{
Studies on Microaerophilic Cocci (Stuart-Schwan Cocci) Isolated from Summer Mastitis and Other Pyogenic Infections of Cattle
}

\author{
By Mogens Madsen \\ Department of Hygiene and Microbiology, \\ Royal Veterinary and Agricultural University, Copenhagen, Denmark.
}

\begin{abstract}
Madsen M.: Studies on microaerophilic cocci (Stuart-Schwan cocci) isolated from summer mastitis and other pyogenic infections of cattle. Acta vet. scand. 1989, 30, 165-174. - Forty-nine strains of microaerophilic gram-positive cocci (StuartSchwan cocci) isolated from summer mastitis, "pyogenes"-mastitis, other pyogenic conditions of Danish cattle and swine, and from the sheep headfly Hydrotaea irritans were biochemically characterized with the API $50 \mathrm{CH}$ and API ZYM test kit systems, and screened for production of a variety of extracellular enzymes by agar plate methods. For comparison 4 strains isolated from Swedish cases of heifer and dry cow mastitis were included in the study.

Similarity calculations indicated a high degree of homogeneity within the strains studied (similarity level $92 \%$; group mean similarity $87 \%$ ). The strains probably represent one species, although the taxonomic position of the organism remains unclear. The biochemical feature of the strains studied were very similar for strains isolated from cases of summer mastitis and strains from other sources of origin. It is suggested that the Stuart-Schwan coccus occurs as a natural cohabitant to $A c$ ttnomyces pyogenes, Peptostreptococcus indolicus and the anaerobic organism characteristic of the bacterial complex isolated from summer mastitis and similar pyogenic conditions in ruminants and swine.
\end{abstract}

API $50 \mathrm{CH}$; API ZYM.

\section{Introduction}

On clinical grounds, summer mastitis in cattle may be defined as an acute suppurative mastitis occurring in non-lactating cows and heifers, predominantly during the summer months, although a similar syndrome occurs occasionally in calves and dry cows at other times of the year (Marshall 1981).

Despite the fact that summer mastitis is also known as Corynebacterium (s. Actinomyces) pyogenes mastitis it should be noted that the isolation of Actinomyces pyogenes is not a prerequisite to classification as summer mastitis. In recent years application of adequate procedures for the culture of more fasti- dious microorganisms have revealed that most cases yield mixed infections with at least 5 to 6 , and possibly more, bacteria present. The main species concerned are $\mathrm{Actl}$ nomyces pyogenes, Peptostreptococcus indolicus, a microaerophilic coccus (Stuart/ Schwan coccus), Streptococcus dysgalactiae, Bacteroides melaninogenicus and Fusobacterium necrophorum (Høl Sørensen 1974, 1978, 1979, Schwan \& Holmberg 1978/ 1979, Tolle et al. 1983, Egan 1986, Madsen 1985, 1987).

Of these bacterial species the Stuart-Schwan cocci still remain to be named and properly classified in the present taxonomic system. 
Essential information on the habitats and biochemical properties of the organism is lacking and it is not quite clear whether all investigators reporting on an "unidentified microaerophilic coccus" refer to the same organism.

Stuart et al. (1951) examined udder secretions from dairy cattle with summer mastitis and reported for the first time the occurrence of a gram-positive organism which they designated a "microaerophilic coccus". The involvement of this organism in the bacterial aetiology of summer mastitis has been confirmed in later studies (Høi Sørensen 1972, 1974, 1978, Schwan 1979, Madsen 1985, Hillerton et al. 1987); recently, the isolations of apparently similar microaerophilic cocci from a range of pyogenic infections of cattle, sheep and goats have been reported (Slee 1985, Slee \& McOrist 1985) suggesting a close association of this organism with Actinomyces pyogenes, Peptostreptococcus indolicus and other anaerobes commonly isolated from pyogenic conditions in ruminants.

In the present communication a number of Danish strains of Stuart-Schwan cocci isolated from mastitis and other pyogenic infections of cattle are characterized by their activity in a variety of biochemical tests.

\section{Materials and methods}

Bacterial strains

Forty-nine strains of microaerophilic grampositive cocci isolated from summer mastitis (20), "pyogenes"-mastitis (22), other pyogenic conditions of Danish cattle and swine (6) and from the headfly Hydrotaea irritans (1) (Table 1) were examined. The bacteria had been isolated from blood agar plates on which they occurred in mixed culture mostly with A.pyogenes, P. indolicus, Streptococcus dysgalactiae and/or Bacteroldaceae. They were tentatively identified as StuartSchwan cocci on the basis of growth characteristics and bacterial morphology as described by Stuart et al. (1951) and Schwan et al (1979). In addition 4 Swedish strains isolated from cases of heifer and dry-cow mastitis (Schwan \& Holmberg 1978/1979) were included in the study for comparison.

\section{Culture media and chemicals}

Blood agar (BA): Tryptose blood agar base (Difco) containing $5 \%$ (vol/vol) defibrinated calf blood (National Veterinary Laboratory, Ringsted Dept.), ph 7.2-7.4.

Peptone-yeast broth (VLB): VL basal medium (Fiévez 1963) with an addition of $0.2 \mathrm{~g}$ glucose (Merck), $0.04 \mathrm{~g} \mathrm{1-cystein} \mathrm{hy-}$ drochloride (Sigma), $1.0 \mathrm{ml}$ hemin-mena-

Table 1. Number of strains, and source of origin, of the investigated strains of microaerophilic cocci (Stuart-Schwan cocci).

\begin{tabular}{cl}
\hline Number of strains & Source of ongin \\
\hline 20 & Summer mastitis \\
22 & Other mastitis, stabled cattle \\
2 & Pulmonary abscess, heifer \\
1 & Hock phlegmone, cow \\
1 & Arthritis, bull \\
1 & Umbilical abscess, calf \\
1 & Croupous pneumonia, swine \\
1 & Sheep headfly (Hydrotaea irrtans) \\
4 & Heifer and dry cow mastitis (Swedish strains) \\
\hline
\end{tabular}


dione solution (Sigma) (Holdeman \& Moore 1973), $0.1 \mathrm{mg}$ resazurin (Sigma), and $0.06 \mathrm{~g}$ Bacto agar (Difco) per $100 \mathrm{ml}, \mathrm{pH} 7.2-7.4$. Hyaluronidase agar: Sodium hyaluronidate (Sigma) agar prepared according to Smith \& Willett (1968).

Tellurite agar: Tryptose blood agar base (Difco) containing $10 \mathrm{mg}$ potassium tellurite (Merck) per $100 \mathrm{ml}(1: 10,000)$.

API $50 \mathrm{CH}$ : Test kit system providing 49 different carbohydrates and carbohydrate derivatives (API System S.A., France).

API ZYM: Test kit system providing 19 different enzyme substrates (API System S.A., France).

All other media: According to Cowan (1974).

With the exception of BA, $10 \%$ ( $\mathrm{vol} / \mathrm{vol})$ horse serum (National Veterinary Laboratory, Ringsted Dept.) was added to all media.

\section{Incubation and maintenance procedures}

For short term storage (4-6 weeks) 48-72 h cultures on BA or in VLB were kept at $4^{\circ} \mathrm{C}$. For prolonged storage $72 \mathrm{~h}$ BA cultures were suspended in horse serum with $7.5 \%$ glucose (wt/vol) and freeze-dried. Prior to examination the strains were subcultured twice on BA to ensure purity.

All solid media were heavily inoculated with a streak of a $48 \mathrm{~h}$ culture and incubated anaerobically by the pyrogallol technique (Fiévez 1963$)$ at $37^{\circ} \mathrm{C}$. Plates were read after 5-7 days.

The API $50 \mathrm{CH}$ and API ZYM test kit systems were, according to the manufacturer's instructions, inoculated in each cupule with two drops of a heavy suspension of bacterial cells in $0.9 \% \mathrm{NaCl}$ recovered from two $48 \mathrm{~h}$ BA plate cultures. The cupules of the API $50 \mathrm{CH}$ kit were covered with liquid paraffin to obtain anaerobic conditions and then incubated at $37^{\circ} \mathrm{C}$ for 35 days. Readings were performed daily during the first week, and subsequently at intervals of 2-3 days. For the API ZYM kit the strips were incubated in moist chambers for $4 \mathrm{~h}$ at $37^{\circ} \mathrm{C}$. API ZYM developing reagents were then added to the cupules, exposed to a strong $(1,000$ W) light source for $5 \mathrm{~min}$, and the reactions read according to a scaled colour chart supplied by the manufacturer. Tests giving grade 0 and grade 1 reactions were regarded as negative whereas reactions of grades 2 to 5 were considered positive.

All Danish strains were tested once and, if doubtful reactions occurred, twice in all substrates. All Swedish strains were tested 3 times.

\section{Similarity calculatıons}

The homogeneity of the strains was studied in a computerized cluster analysis programme (Chr. Rovsing A/S) routinely used in identification procedures at the Institute of Hygiene and Microbiology. The programme calculates mean similarities, expressed as a similarity matrix, within and between groups (clusters) at a specified level. A comparison was performed at $80 \%, 85 \%, 90 \%$, and $95 \%$ levels of similarity.

\section{Results}

\section{Growth characteristics}

All strains grew on BA aerobically, anaerobically and in atmospheric air containing $10 \%$ carbon dioxide. Visible colonies appeared after 2 to 3 days of incubation anaerobically and in $10 \%$ carbon dioxide, whereas aerobic growth was slower with visible colonies as a rule appearing after 4 to 5 days of incubation.

Satellitism was a constant feature when strains were co-cultivated with $A$.pyogenes or Micrococcus spp. However all strains grew without "helper" colonies as well. As compared to ordinary blood agar, growth 
was enhanced on chocolate agar and lecithovitellin agar.

\section{Colony morphology}

Two days of incubation anaerobically produced pin-point colonies which on continued incubation developed into small $(\mathrm{d}=$ 1.0-1.5 mm), smooth, translucent dew-drop colonies. None of the strains produced haemolysis on the bovine blood agar employed but all strains produced zones of greening around the colonies when left for several days at room temperature.

\section{Cell morphology}

In gram-stained smears and India ink preparations from broth cultures the bacteria were coccoid, somewhat uneven in size $(\mathrm{d}=$ 1.0-1.5 $\mu \mathrm{m}$ ), and were arranged singly, in pairs, clumps, or short chains of 3 to 4 cells. In fresh cultures the bacteria were grampositive whereas older cultures were gramlabile. In older cultures large coccal forms were often observed. Capsule formation was not detected using phase-contrast microscopy or ordinary microscopy of India ink preparations.

\section{Catalase and cytochrome oxidase}

None of the strains produced catalase or cytochrome oxidase.

\section{Motility}

All strains were non-motile when examined by phase-contrast microscopy of $48 \mathrm{~h}$ broth cultures.

\section{OF test}

All strains attacked glucose fermentatively in Hugh \& Leifson's medium. Acid production was weak and most strains had to be incubated for 5 to 7 days before a definite reading could be performed.
API $50 \mathrm{CH}$

All strains were positive in the ribose, fructose, $\mathrm{N}$-acetylglucosamine, esculin, lactose, D-turanose and D-tagatose tests, and all were negative in the erythritol, adonitol, $\beta$-methylxyloside, rhamnose, dulcitol, inositol, $\alpha$-methylmannoside, inulin, L-arabitol and 2-ketogluconate tests, whereas the remaining characters were variable. Late fermentation reactions were recorded in a number of substrates (Table 2).

In 40 of the 49 substrates tested in the API $50 \mathrm{CH}$ system the bacterial strains gave very similar reactions, where a "typical" reaction is defined as positive or negative in $80 \%$ or more of strains tested (see Table 2). A subdivision of strains according to source of origin (Table 3) did not reveal any significant differences between strains of different origin.

\section{API ZYM and extracellular enzymes}

All strains were positive for esterase, esterase lipase, leucine arylamidase, phosphoamidase, hyaluronidase and tellurite reduction $(1: 10,000)$, and all were negative for amylase, lecithinase and caseinase. With a typical reaction defined as above, the reactivity pattern was consistent for 20 of the 24 tests (Table 4). No significant differences were recorded between strains from different sources.

\section{Miscellaneous tests}

Five strains were subjected to indole, methyl red, Voges-Proskauer, nitrate reduction, esculin, bile solubility and optochin sensitivity tests in conventional media. All strains were negative.

The 5 strains were sensitive to chloramphenicol, tetracycline and cephalosporins, and resistant to novobiocin and polymyxin B when tested on BA by the disc sensitivity method (NeoSensitabs, Rosco). 
Table 2. Biochemical reactions of 49 Danish strains of StuartSchwan cocci in the API $50 \mathrm{CH}$ system.

Positive reaction in relation to time.

\begin{tabular}{|c|c|c|c|c|c|c|}
\hline \multirow[b]{2}{*}{ Substrate } & \multicolumn{5}{|c|}{$\begin{array}{l}\text { Total number of strains } \\
\text { positive on day }\end{array}$} & \multirow[t]{2}{*}{$\begin{array}{l}\text { Posittve } \\
(\%)\end{array}$} \\
\hline & 1 & 2 & 5 & 15 & 35 & \\
\hline Glycerol & 0 & 3 & 4 & 10 & 13 & 27 \\
\hline Erythritol & 0 & 0 & 0 & 0 & 0 & 0 \\
\hline D-arabinose & 0 & 0 & 0 & 38 & 45 & 92 \\
\hline L-arabinose & 0 & 0 & 0 & 32 & 38 & 78 \\
\hline Ribose & 0 & 0 & 3 & 46 & 49 & 100 \\
\hline D-xylose & 0 & 0 & 0 & 39 & 43 & 88 \\
\hline L-xylose & 0 & 0 & 0 & 38 & 46 & 94 \\
\hline Adonitol & 0 & 0 & 0 & 0 & 0 & 0 \\
\hline Beta-methyl-xyloside & 0 & 0 & 0 & 0 & 0 & 0 \\
\hline Galactose & 28 & 34 & 35 & 44 & 46 & 94 \\
\hline Glucose & 15 & 21 & 22 & 35 & 38 & 78 \\
\hline Fructose & 27 & 33 & 34 & 48 & 49 & 100 \\
\hline Mannose & 22 & 28 & 29 & 43 & 43 & 88 \\
\hline Sorbose & 0 & 0 & 0 & 40 & 43 & 88 \\
\hline Rhamnose & 0 & 0 & 0 & 0 & 0 & 0 \\
\hline Dulcitol & 0 & 0 & 0 & 0 & 0 & 0 \\
\hline Inositol & 0 & 0 & 0 & 0 & 0 & 0 \\
\hline Mannitol & 0 & 0 & 0 & 2 & 2 & 4 \\
\hline Sorbitol & 0 & 0 & 0 & 1 & 1 & 2 \\
\hline Alpha-methyl-mannoside & 0 & 0 & 0 & 0 & 0 & 0 \\
\hline Alpha-methyl-glucoside & 0 & 0 & 0 & 41 & 41 & 84 \\
\hline $\mathrm{N}$-acetyl-glucosamine & 36 & 41 & 42 & 49 & 49 & 100 \\
\hline Amygdalin & 0 & 5 & 6 & 10 & 10 & 21 \\
\hline Arbutin & 1 & 3 & 3 & 9 & 10 & 21 \\
\hline Esculin & 0 & 4 & 4 & 47 & 49 & 100 \\
\hline Salicin & 4 & 14 & 16 & 44 & 44 & 90 \\
\hline Cellobiose & 5 & 21 & 21 & 43 & 44 & 90 \\
\hline Maltose & 14 & 21 & 23 & 35 & 38 & 78 \\
\hline Lactose & 28 & 40 & 42 & 48 & 49 & 100 \\
\hline Melibiose & 0 & 1 & 1 & 2 & 2 & 4 \\
\hline Sucrose & 2 & 5 & 6 & $4 \overline{3}$ & $4 \overline{4}$ & 90 \\
\hline Trehalose & $2 \overline{6}$ & 33 & 34 & 46 & 46 & 94 \\
\hline Inulin & 0 & 0 & 0 & 0 & 0 & 0 \\
\hline Melezitose & 0 & 2 & 2 & 40 & 42 & 86 \\
\hline Raffinose & 0 & 0 & 0 & 3 & 3 & 6 \\
\hline Amidon & 17 & 28 & 29 & 38 & 38 & 78 \\
\hline Glycogen & 19 & 26 & 27 & 35 & 35 & 71 \\
\hline Xylitol & 0 & 0 & 0 & 1 & 1 & 2 \\
\hline Gentiobiose & 0 & 10 & 11 & 15 & 16 & 33 \\
\hline D-turanose & 28 & 34 & 35 & 47 & 49 & 100 \\
\hline D-lyxose & 0 & 1 & 1 & 44 & 46 & 94 \\
\hline D-tagatose & 5 & 12 & 14 & 47 & 49 & 100 \\
\hline D-fucose & 0 & 0 & 0 & 1 & 1 & 2 \\
\hline L-fucose & 0 & 0 & 0 & 2 & 3 & 6 \\
\hline D-arabitol & 0 & 0 & 0 & 1 & 1 & 2 \\
\hline L-arabitol & 0 & 0 & 0 & 0 & 0 & 0 \\
\hline Gluconate & 0 & 0 & 0 & 1 & 1 & 2 \\
\hline 2-keto-gluconate & 0 & 0 & 0 & 0 & 0 & 0 \\
\hline 5-keto-gluconate & 1 & 12 & 18 & 46 & 47 & 96 \\
\hline
\end{tabular}


Table 3. Biochemical reactions of 53 strains of Stuart-Schwan cocci in the API 50 $\mathrm{CH}$ system, grouped according to source of origin.

\begin{tabular}{|c|c|c|c|c|c|}
\hline Substrate & $\begin{array}{l}\text { Summer } \\
\text { mastitts } \\
(20)\end{array}$ & $\begin{array}{c}\text { Other } \\
\text { mastitis } \\
(22)\end{array}$ & $\begin{array}{l}\text { Other } \\
\text { 1solates } \\
\text { (7) }\end{array}$ & $\begin{array}{l}\text { Total } \\
\text { (49) }\end{array}$ & $\begin{array}{c}\text { Swedish } \\
\text { strains } \\
\text { (4) }\end{array}$ \\
\hline Glycerol & d & d & d & d & d \\
\hline Erythritol & - & - & - & - & - \\
\hline D-arabinose & + & + & + & + & + \\
\hline $\mathrm{L}$-arabinose & d & d & d & d & + \\
\hline Ribose & + & + & + & + & + \\
\hline D-xylose & + & d & + & + & + \\
\hline L-xylose & + & + & + & + & + \\
\hline Adonitol & - & - & - & - & - \\
\hline Beta-methyl-xyloside & - & - & - & - & - \\
\hline Galactose & + & + & d & + & + \\
\hline Glucose & d & + & d & $\mathrm{d}$ & + \\
\hline Fructose & + & + & + & + & + \\
\hline Mannose & + & + & d & + & + \\
\hline Sorbose & + & d & + & + & + \\
\hline Rhamnose & - & - & - & - & - \\
\hline Dulcitol & - & - & - & - & - \\
\hline Inositol & - & - & - & - & - \\
\hline Mannitol & - & - & - & - & - \\
\hline Sorbitol & - & - & - & - & d \\
\hline Alpha-methyl-mannoside & - & - & - & - & - \\
\hline Alpha-methyl-glucoside & d & + & + & + & d \\
\hline $\mathrm{N}$-acetyl-glucosamine & + & + & + & + & + \\
\hline Amygdalin & d & d & - & $\mathrm{d}$ & d \\
\hline Arbutin & $\mathrm{d}$ & d & - & $\mathrm{d}$ & $\mathrm{d}$ \\
\hline Esculin & + & + & + & + & + \\
\hline Salicin & + & + & d & + & + \\
\hline Cellobiose & + & + & + & + & + \\
\hline Maltose & d & + & d & d & + \\
\hline Lactose & + & + & + & + & + \\
\hline Melibiose & - & - & - & - & - \\
\hline Sucrose & + & + & + & + & d \\
\hline Trehalose & + & + & + & + & + \\
\hline Inuline & - & - & - & - & - \\
\hline Melezitose & d & + & + & + & d \\
\hline Raffinose & - & - & - & - & - \\
\hline Amidon & d & + & d & d & + \\
\hline Glycogen & d & + & d & d & + \\
\hline Xylitol & - & - & - & - & - \\
\hline Gentiobiose & d & d & d & d & d \\
\hline D-turanose & + & + & + & + & + \\
\hline D-lyxose & + & + & + & + & + \\
\hline D-tagatose & + & + & + & + & + \\
\hline D-fucose & - & - & - & - & - \\
\hline L-fucose & - & - & - & - & - \\
\hline D-arabitol & - & - & - & - & - \\
\hline L-arabitol & - & - & - & - & - \\
\hline Gluconate & - & - & - & - & - \\
\hline 2-keto-gluconate & - & - & - & - & - \\
\hline 5-keto-gluconate & + & + & + & + & + \\
\hline
\end{tabular}

Symbols: $-0-20 \%$ positive, $\mathrm{d} 21-79 \%$ positive, $+80-100 \%$ positive. 
Table 4. Enzymatic reactions of 53 strains of Stuart-Schwan cocci in the API ZYM system, grouped according to source of origin.

\begin{tabular}{|c|c|c|c|c|c|}
\hline Substrate & $\begin{array}{l}\text { Summer } \\
\text { mastitis } \\
(20)\end{array}$ & $\begin{array}{c}\text { Other } \\
\text { mastitis } \\
(22)\end{array}$ & $\begin{array}{c}\text { Other } \\
\text { 1solates } \\
\text { (7) }\end{array}$ & $\begin{array}{l}\text { Total } \\
(49)\end{array}$ & $\begin{array}{c}\text { Swedish } \\
\text { strains } \\
\text { (4) }\end{array}$ \\
\hline Alkalıne phosphatase & + & + & + & + & + \\
\hline Esterase (C4) & + & + & + & + & + \\
\hline Esterase lipase (C8) & + & + & + & + & + \\
\hline Lipase (C14) & - & - & - & - & - \\
\hline Leucine arylamidase & + & + & + & + & + \\
\hline Valine arylamidase & - & d & - & d & - \\
\hline Cystine arylamidase & + & + & + & + & + \\
\hline Trypsin & - & - & - & - & - \\
\hline Chymotrypsin & - & - & d & - & - \\
\hline Acid phosphatase & + & + & + & + & + \\
\hline Phosphoamidase & + & + & + & + & + \\
\hline Alfa-galactosidase & - & - & - & - & - \\
\hline Beta-galactosidase & $\mathrm{d}$ & d & d & d & d \\
\hline Beta-glucuronidase & - & - & - & - & - \\
\hline Alfa-glucosidase & d & d & d & d & + \\
\hline Beta-glucosidase & - & - & - & - & - \\
\hline $\begin{array}{l}\mathrm{N} \text {-acetyl-beta- } \\
\text { glucosaminidase }\end{array}$ & $\mathrm{d}$ & d & d & d & + \\
\hline Alfa-mannosidase & - & - & - & - & - \\
\hline Alfa-fucosidase & - & - & - & - & - \\
\hline Hyaluronidase & + & + & + & + & + \\
\hline Amylase & - & - & - & - & - \\
\hline Lecithinase & - & - & - & - & - \\
\hline Caseinase & - & - & - & - & - \\
\hline $\begin{array}{l}\text { Tellurite reduction } \\
(1: 10,000)\end{array}$ & + & + & + & + & + \\
\hline
\end{tabular}

Symbols as in Table 3 .

\section{Similarity calculations}

A comparison of all strains at $80 \%, 85 \%$ and $90 \%$ levels of similarity described all strains as one homogenous cluster, whereas 9 strains were excluded without being able to form a separate cluster when the level of similarity was increased to $95 \%$. The 9 strains were distributed in the 3 subgroups, viz. summer mastitis 3 (of 20), other mastitis 4 (of 22), and other isolates 2 strains (of 7). At a similarity level of $92 \%$ no strains were excluded, and the strains displayed homogeneity with a group mean similarity of $87 \%$.

\section{Discussion}

On the whole the cultural and biochemical features of the strains studied showed a high degree of similarity and it thus seems likely that the strains examined represent one species. The homogeneity included the Swedish reference strains as well (cf. Table 3 and 4). According to the limited description given by Stuart et al. (1951), and to the more extensive examination carried out by Schwan et al. (1979), it seems reasonable that the strains studied herein are identical to the microaerophilic cocci isolated from English and Swedish cases of heifer and dry cow 
mastitis. Also, the findings conform to the description of microaerophilic cocci recently isolated from pyogenic infections of ruminants in Australia (Slee 1985). Minor differences in fermentation reactions as regards arabinose, ribose, xylose, sucrose and esculin may be noted but these differences may be most easily explained by differences in incubation periods; in the present investigation all carbohydrates were incubated for 35 days, compared with 24 h (Slee 1985), or 48 h (Schwan et al. 1979) in earlier studies. As may be seen from Table 2 a substantial number of carbohydrate fermentation tests in the present study were negative after $24 \mathrm{~h}$ or $48 \mathrm{~h}$ of incubation but became positive on prolonged incubation, which seems to correlate well with the records of the slow growth of this organism.

In agreement with the results of Stuart et al. (1951) one of the distinct features of the strains in the present series was the satellitic growth exhibited around other bacterial colonies such as those of A.pyogenes. Although freshly isolated strains can be adapted by serial subculture to become independent of helper bacteria the feature strongly suggests an almost symbiotic relationship between the members of the complex of bacteria isolated from summer mastitis and other infectious conditions commonly known as "pyogenes"-infections. This view is supported by the observations of $\mathrm{Høi}$ Sørensen (1980) in which a stimulating effect of $P$. indolicus and the Stuart-Schwan coccus on the toxin production of $A$. pyogenes was demonstrated. The active participation of the Stuart-Schwan coccus in the pathogenesis of summer mastitis seems obvious as judged by the studies of Schwan (1980) in which high and prolonged IgG titres against the Stuart-Schwan coccus were recorded in experimentally infected animals. The specific contribution of the organism in the pathogenesis is somewhat obscure, but might be attributed to its production of hyaluronidase (Høi Sørensen 1972, Schwan et al. 1979), a potential virulence factor produced by all strains in the present study as well.

In light of the recent reports of the isolation of similar cocci from pyogenic infections other than mastitis (Slee 1985, Slee \& McOrist 1985), and on the grounds of the homogeneity of isolates from various sources including swine and the sheep headfly $H$. urritans in the present investigation, it seems logical to assume that the StuartSchwan coccus is a natural cohabitant to $A$. pyogenes, $P$. indolicus and the other microorganisms involved in this complex.

The taxonomic position of the StuartSchwan cocci remains unsolved. Identification as micrococci, staphylococci or anaerobic cocci seems highly unlikely, and, although some characteristics such as microaerophilic growth, hyaluronidase production and a moderate resistance to tellurite suggest a relatedness to streptococci, this is not consistent with the end products of its glucose metabolism (Schwan et al. 1979). Furthermore, attempts to identify isolates by Lancefield grouping have not been successful (Slee 1985, own unpublished results). Thus a proper taxonomic classification awaits the application of more sophisticated methods such as the determination of guanin plus cytosin content and DNA/RNA homology values.

\section{Acknowledgements}

My sincere thanks are due to Dr. Gunner Høi Sørensen, National Veterınary Laboratory, Aarhus Branch, for providing the Danish strains of the Stuart-Schwan cocci. Thanks are also due to Dr. Olof Schwan, Swedish University of Agricultural Science, Uppsala, for the provision of the Swedish reference strains. The skilful technical assistance of Ms. Marianne Christiansen in performing the 
practical laboratory work is very much appreciated. This work was supported by grant no. 13-1773 from The Danish Agricultural and Veterinary Research Council.

\section{References}

Cowan ST Cowan \& Steel's Manual for the Identification of Medical Bacteria. Cambridge Un1versity Press, London 1974.

Egan $J$ Bacteriology of summer mastitis secretions from cattle in Eire. Vet. Rec. 1986, 119, 358.

Fiévez $L$ Etude comparee des souches de Sphaerophorus necrophorus isolees chez l'Homme et chez l'Anımal. (Comparative studies of strains of Sphaerophorus necrophorus isolated from man and anımals). Presses Acad. Europ., Bruxelles 1963.

Hillerton JE, Bramley AJ, Watson CA The ep1demiology of summer mastitis; a survey of clinical cases. Brit. vet. J. 1987, 143, 520-530.

Holdeman LV, Moore WEC Anaerobe Laboratory Manual, 2nd ed. Virgınıa Polytechnıc Institute and State University Anaerobe Laboratory, Blacksburg, Vırginia 1973.

Høı Sørensen G Sommermastitıs - eksperimentelt fremkaldt hos juvenile kvier. (Summer mastitis - experimentally produced in juvenıle heifers). Nord. Vet.-Med. 1972, 24, 247-258.

Hol Sørensen $G$ Studies on the aetiology and transmission of summer mastitıs. Nord. Vet.Med. 1974, 26, 122-133.

Høı Sørensen $G$ Bacteriological examination of summer mastitis secretions. The demonstration of Bacteroldaceae. Nord. Vet.-Med. 1978, 30, 199-204.

Høı Sørensen $G$ Sommermastitıs. (Summer mastitis). Thesis, Carl Fr. Mortensen, Copenhagen 1979.

Høı Sørensen G Comparatıve studies on Corynebacterium pyogenes toxin formation in monocultures and mixed cultures - the demonstration of a stımulatıng effect of Peptococcus indolicus and Stuart-Schwan cocc1. Acta vet. scand. $1980,21,443-448$.

Madsen M. Sommermastitis. Bakteriologiske og transmissionsdynamiske undersøgelser. (Summer mastitis. Investigations on the bacteriology and transmission dynamics). Ph. D. thes1s, Copenhagen 1985.

Madsen, M. The bacteriology of summer mast1tis. In: Summer mastitıs (ed. G. Thomas et al.), Proc. CEC Workshop Oct. 1986. Mart1nus Nijhoff, Lancaster 1987.

Marshall $A B$ Summer mastitis. NIRD Techn. Bull. 1981, 4, 81-94.

Schwan $O$ Heifer mastitis and dry cow mastitis. Bacteriological and serological incestigations with special reference to mixed infection with Corynebacterium pyogenes, Peptococcus indolicus and microaerophilic cocci. Thesis, Sveriges Lantbruksuniversitet, Uppsala 1979.

Schwan $O$ IgG antibody response to Corynebacterium pyogenes, Peptococcus indolicus and microaerophilic cocci in natural and experimental mastitis. Vet. Microbıol. 1980, 5, 19-34.

Schwan $O$, Holmberg $O$ Heifer mastitis and dry cow mastitis. A bacterological survey in Sweden. Vet. Microbiol. 1978/1979, 3, 213-226.

Schwan $O$, Nord CE, Holmberg $O$ Biochemical characterization of unıdentified microaerophilic coccl isolated from heifer and dry-cow mastitıs. J. Clın. Microbiol. 1979, 10, 622627.

Slee $K J \cdot$ A microaerophilic coccus in pyogenic infections of ruminants. Aust. Vet. J. 1985, 62, 57-59.

Slee, KJ, McOrist $S$ Mastitis due to a group of pyogenic bacteria. Aust. Vet. J. 1985, 62, 6365.

Smith $R F$, Willett NP. Rapid plate method for screening hyaluronidase and chondroitin sulphatase-producing organisms. Appl. Microbiol. 1968, 16, 1434-1436.

Stuart $P$, Buntain D, Langridge $R G \cdot$ Bacteriological examination of secretions from cases of "summer mastitis" and experimental infection of non-lactating bovine udders. Vet. Rec. 1951. 63, 451-453.

Tolle A, Franke V, Reichmuth J: Zur C. Pyogenes-Mastitis - Bacteriologische aspekte (C. pyogenes-mastitis - bacterological aspects). Dtsch. Tierarztl. Wschr. 1983, 90, 256-260. 


\author{
Sammendrag \\ Studier over mikroaerofile kokker (Stuart-Schwan \\ kokker) isoleret fra sommermastitis og andre \\ pyogene infektioner hos kvag \\ 49 stammer af grampositıve, mikroaerofile kokker \\ (Stuart-Schwan kokker) isoleret fra tilfælde af \\ sommermastitis, "pyogenes-mastitis", andre pyo- \\ gene processer fra danske køer og svin, samt fra \\ plantagefluen Hydrotaea trritans, karakteriseredes \\ ved deres biokemiske profil i testsystemerne API \\ $50 \mathrm{CH}$ og API ZYM. Desuden undersøgtes stam- \\ mernes produktion af extracellulære enzymer un- \\ der anvendelse af udvalgte pladesubstrater. 4 \\ stammer isoleret fra svenske tilfælde af sommer- \\ mastitis og goldkomastitis inkluderedes $\mathrm{i}$ under- \\ søgelsen som referencestammer.
}

Similaritetsstudier placerede alle undersøgte stammer $\mathrm{i}$ een gruppe på et højt similaritetsniveau (92\%), med en indbyrdes similaritet på $87 \%$. De undersøgte stammer udgør formentlig een species, omend den eksakte taksonomiske placering endnu er uafklaret.

Der kunne ikke påvises nogle væsentlige forskelle mellem den biokemiske profil af stammer isoleret fra mastitistilfælde og stammer af anden oprındelse. Det må således antages, at Stuart-Schwan kokken findes naturligt associeret til Actinomyces pyogenes, Peptostreptococcus indolicus og andre anaerobe bakterier, der indgår i det kompleks af bakterier, der ofte isoleres fra sommermastitis og lignende pyogene infektioner hos drøvtyggere og svin.

(Accepted August 11, 1988)

Reprints may be requested from: Mogens Madsen, Veterinary Research Laboratory, P. O. Box 8101, Causeway, Harare, Zimbabwe. 